\title{
Bioremediation of Agro-Based Pulp Mill Effluent by Microbial Consortium Comprising Autochthonous Bacteria
}

\author{
Virendra Kumar, ${ }^{1}$ Purnima Dhall, ${ }^{1}$ Rita Kumar, ${ }^{1}$ Yogendra Prakash Singh, ${ }^{1}$ and Anil Kumar ${ }^{2}$ \\ ${ }^{1}$ Environmental Biotechnology Division, Institute of Genomics and Integrative Biology, Mall Road, Delhi 110007, India \\ ${ }^{2}$ Patent Division, National Institute of Immunology, Aruna Asaf Ali Marg, New Delhi 110067, India \\ Correspondence should be addressed to Rita Kumar, rita@igib.res.in
}

Received 3 October 2011; Accepted 23 October 2011

Academic Editor: Angel Concheiro

Copyright (C) 2012 Virendra Kumar et al. This is an open access article distributed under the Creative Commons Attribution License, which permits unrestricted use, distribution, and reproduction in any medium, provided the original work is properly cited.

\begin{abstract}
Small-scale agro-based pulp and paper mills are characterized as highly polluting industries. These mills use Kraft pulping process for paper manufacturing due to which toxic lignified chemicals are released into the environment. Lack of infrastructure, technical manpower, and research and development facilities restricts these mills to recover these chemicals. Therefore, the chemical oxygen demand (COD) of the emanating stream is quite high. For solving the above problem, four bacteria were isolated from the premises of agro-based pulp and paper mill which were identified as species of Pseudomonas, Bacillus, Pannonibacter, and Ochrobacterum. These bacteria were found capable of reducing COD up to $85 \%-86.5 \%$ in case of back water and $65-66 \%$ in case of back water : black liquor $(60: 40)$, respectively, after acclimatization under optimized conditions ( $\mathrm{pH} 6.8$, temperature $35^{\circ} \mathrm{C}$, and shaking $200 \mathrm{rpm}$ ) when the wastewater was supplemented with nitrogen and phosphorus as trace elements.
\end{abstract}

\section{Introduction}

Paper mills based on nonconventional agro residues are being encouraged due to increased demand of paper and acute shortage of forest-based raw materials. Small-scale pulp and paper mills are generally situated in rural areas due to availability of raw materials (wheat straw, rice straw, and baggase). The agro-based pulp and paper mills are highly water intensive, consuming $100-250 \mathrm{~m}^{3}$ fresh water/ton paper produced [1]. These units correspondingly generate large quantities of wastewater, approximately $150-200 \mathrm{~m}^{3}$ effluent/ton of paper produced. The environmental impact of wastewater emanated from small-scale pulp and paper mills is therefore of particular concern [2]. The paper manufacturing process involves three steps, pulping, bleaching, and finally paper making. Pulping can be done via chemical (Kraft pulping) or mechanical methods. Chemical pulping is the most commonly employed pulping technique in agro-based pulping mills [3]. The effluent emanating from the pulping process is called black liquor and it contains inorganic chemicals, chlorophenolic compounds, and fibre residues which have characteristically high levels of biochemical oxygen demand
(BOD), chemical oxygen demand (COD), suspended solids, color, and organic compounds [4]. The discharge of black liquor from 30 ton per day agro-based pulp and paper mills without chemical recovery yields pollution load equivalent to a 100 tpd mill with chemical recovery [5]. The main component of this type of wastewater is chlorolignin. For ages, lignin has been well known for its resistance to microbial degradation because of its high molecular weight and presence of various biologically stable carbon-to-carbon and ether linkages [6]. But of late, few bacteria have been reported to be able to degrade lignin [7]. However, not much work has been undertaken towards lignin degradation by bacteria. In addition, the chlorophenolic compounds formed in chlorine bleaching are toxic, persist, bioaccumulate, and transform into other compounds which are more hazardous. Government agencies mark the standards for the discharge of wastewater into the environment; the BOD standard of $30 \mathrm{mg} / \mathrm{L}$ for discharge on inland surface water and $100 \mathrm{mg} / \mathrm{L}$ for disposal has been notified under the environment protection rule.

However, agro-based small-scale pulp and paper industries do not treat their wastewater to bring these parameters 
to the level of the standards laid down by the government bodies. They use sulfuric acid and polyelectrolyte for precipitation of lignin which also removes color from the effluent because lignin gets precipitated at acidic $\mathrm{pH}$ [8]. This treatment is very expensive and harmful for aquatic life, therefore it needs to be replaced by environmental friendly method.

Of late, biological treatment came in to scenario in these systems, where wide variety of microorganisms including fungi, actinomycetes, and bacteria have been implicated in biodegradation of lignin via an oxidative process [9-11]. Fungi contain lignin peroxidases, manganese peroxidases, and so forth, which can effectively degrade lignin, but they are unable to work efficiently under extreme environmental conditions, namely, high temperature, $\mathrm{pH}$, and presence of toxic chemicals which usually exist in the treatment plants. In addition, fungal filaments cause structural hindrance, so its utilization is not feasible for biological treatment of pulp and paper industry effluent [11]. In the above context, efforts were diverted to isolate specific novel bacteria which can survive under such extreme environment and can effectively degrade organic matter present in the pulp and paper industry effluent. Present study exploits biodegradable potential of autochthonous bacteria to treat the industrial effluent from agro-based small-scale pulp and paper mills to bring the wastewater characteristics within the permissible limits involving less retention time.

\section{Materials and Methods}

2.1. Chemicals, Reagents, Glassware, and Media. All chemicals, reagents, and media used in the present study were of analytical grade and obtained from Hi-Media, India. The laboratory glass wares used were washed with detergents and rinsed with distilled water then oven baked at $200^{\circ} \mathrm{C}$ overnight, prior to use.

2.2. Sample Collection. Activated sludge, soil, and wastewater samples were collected from effluent treatment plant of pulp and paper mills located in Meerut, India. Samples were collected and stored at $4{ }^{\circ} \mathrm{C}$ till further use.

2.3. Isolation of Bacteria. For isolation of bacteria, serial dilution technique was performed. Enrichment medium was prepared by adding $5 \mathrm{~g}$ of sludge to a conical flask $(250 \mathrm{~mL})$ containing $100 \mathrm{~mL}$ MSM (minimal salt medium) supplemented with lignin $0.2 \%$. Similarly, enrichment flasks were prepared for tannic acid $0.2 \%$, xylan $1.0 \%$, and cellulose $1.0 \%$. Enrichment of soil was carried out for a period of $48 \mathrm{~h}$ at $30^{\circ} \mathrm{C}$ and $200 \mathrm{rpm}$. This enriched soil was later used for serial dilution. Serial dilutions were prepared in $0.85 \%$ sodium chloride in distilled water, and $100 \mu \mathrm{L}$ of each dilution was spread on solid medium containing MSM supplemented with lignin, tannic acid, xylan, and cellulose separately. The plates were incubated at $35^{\circ} \mathrm{C}$ for $48 \mathrm{~h}$, and bacterial colonies were isolated on the basis of color, size, morphology, and arrangement.

2.4. Screening of Bacteria. Different bacterial isolates were screened for their ability to degrade pulp and paper wastewater. Samples were collected from two different mills, Mill A and Mill B. Two types of samples, namely, back water $(100 \%)$ and back water: black liquor $(60: 40)$ were collected for the study. The inoculum (mother culture) was prepared by inoculating one loopful of all individual bacterial isolates in $25 \mathrm{~mL}$ of sterilized nutrient broth. The inoculated broths were incubated in an orbital shaker at $37^{\circ} \mathrm{C}$ for $16-24 \mathrm{~h}$ so as to obtain actively growing mother cultures. The abovementioned actively growing cultures were inoculated separately in $100 \mathrm{~mL}$ of sterilized nutrient broth and incubated at $35^{\circ} \mathrm{C}, 120 \mathrm{rpm}$ for $16-24 \mathrm{~h}$. All the isolates were taken in $50 \mathrm{~mL}$ graduated centrifuge tube and centrifuged at $7000 \mathrm{rpm}$ for 20 minutes at $4^{\circ} \mathrm{C}$. After centrifugation, supernatant was discarded and the pellet was washed twice with $50 \mathrm{mM}$ sodium phosphate buffer. Bacterial pellet was inoculated in $100 \mathrm{~mL}$ of wastewater sample (sample and culture ratio was $1: 1$ ).

Flasks were incubated for $45 \mathrm{hrs}$ at $35^{\circ} \mathrm{C}$ and $200 \mathrm{rpm}$. After $45 \mathrm{hrs}$, the sample was taken and COD was estimated as per standard methods [12].

2.5. Formulation of Consortia. The nature of pulp and paper industry effluent is quite complex as it contains a number of organic components, for example, lignin, tannic acid, resin, cellulose, and hemicellulose which are difficult to be degraded by a single bacterial isolate. So, there is a need for the formulation of effective microbial consortium which can biodegrade the effluent in minimum time period. The bacterial isolates R1, R5, R10, R12, R21, R24, R25, R27, L1, L6, L10, L13, L14, and L16 were selected for the formulation of consortia on the basis of their rapid growth on nutrient media (MD1, MD2, MD3, and MD4) containing cellulose, xy-lan, tannic, acid, and lignin, respectively, as carbon source (Table 1). Total six consortia (C1, C2, C3, C4, C5, and C6) were formulated, each composed of 4 different isolates (Table 2).

2.6. Screening of Formulated Consortia. Wastewater samples were inoculated with the inoculum in the ratio $1: 1$. The inoculum was prepared by inoculating one loopful of all the 4 individual bacterial isolates separately in $25 \mathrm{~mL}$ sterilized nutrient broth. The inoculated broths were incubated in an orbital shaker at $35^{\circ} \mathrm{C}$ for $16-24$ hours so as to obtain actively growing mother cultures. After achieving the desired growth (1.2 optical density), the cultures were centrifuged at $7000 \mathrm{rpm}$ for $15 \mathrm{~min}$ at $4^{\circ} \mathrm{C}$. The $250 \mathrm{~mL}$ of flasks containing $100 \mathrm{~mL}$ of wastewater sample were inoculated with the pellets and incubated in shaker at $200 \mathrm{rpm}$ at $35^{\circ} \mathrm{C}$. After each 20 hour time interval, $80 \mathrm{~mL}$ treated sample was withdrawn and same amount of untreated effluent was added. This step was repeated twice to achieve better COD reduction. Treated samples were collected at different time intervals, and COD was estimated [12] (APHA). Different parameters like temperature, $\mathrm{pH}$, agitation, and so forth were optimized to achieve maximum reduction in COD of effluent.

2.7. Optimization of Parameters. Effluent generated from pulping (black liquor) is highly concentrated and toxic so, 
TABLE 1: Media used for screening of bacterial isolates for the formulation of consortia.

\begin{tabular}{|c|c|c|c|}
\hline $\begin{array}{l}\text { Medium } \\
\text { (laboratory }\end{array}$ & \multicolumn{2}{|c|}{ Medium composition } & \multirow{2}{*}{ Bacterial isolates } \\
\hline \multirow{7}{*}{ MD1 } & Sludge infusion & $400 \mathrm{~mL}$ & \\
\hline & Distilled water & $600 \mathrm{~mL}$ & \multirow{6}{*}{$\begin{array}{l}\text { R12, L14, R24, } \\
\text { L13 }\end{array}$} \\
\hline & $\mathrm{K}_{2} \mathrm{HPO}_{4}$ & $0.5 \mathrm{~g}$ & \\
\hline & $\mathrm{KH}_{2} \mathrm{PO}_{4}$ & $0.5 \mathrm{~g}$ & \\
\hline & $\mathrm{MgSO}_{4}$ & $0.5 \mathrm{~g}$ & \\
\hline & Cellulose & $10.0 \mathrm{~g}$ & \\
\hline & Agar & $20.0 \mathrm{~g}$ & \\
\hline \multirow{7}{*}{ MD2 } & Sludge infusion & $400 \mathrm{~mL}$ & \multirow{7}{*}{$\begin{array}{l}\text { R1, R5, R10, R12 } \\
\text { R21, L14 }\end{array}$} \\
\hline & Distilled water & $600 \mathrm{~mL}$ & \\
\hline & $\mathrm{K}_{2} \mathrm{HPO}_{4}$ & $0.5 \mathrm{~g}$ & \\
\hline & $\mathrm{KH}_{2} \mathrm{PO}_{4}$ & $0.5 \mathrm{~g}$ & \\
\hline & $\mathrm{MgSO}_{4}$ & $0.5 \mathrm{~g}$ & \\
\hline & Xylan & $10.0 \mathrm{~g}$ & \\
\hline & Agar & $20.0 \mathrm{~g}$ & \\
\hline \multirow{7}{*}{ MD3 } & Sludge infusion & $400 \mathrm{~mL}$ & \multirow{7}{*}{$\begin{array}{l}\text { R12, R25, L6, } \\
\text { L14, L16 }\end{array}$} \\
\hline & Distilled water & $600 \mathrm{~mL}$ & \\
\hline & $\mathrm{K}_{2} \mathrm{HPO}_{4}$ & $0.5 \mathrm{~g}$ & \\
\hline & $\mathrm{KH}_{2} \mathrm{PO}_{4}$ & $0.5 \mathrm{~g}$ & \\
\hline & $\mathrm{MgSO}_{4}$ & $0.5 \mathrm{~g}$ & \\
\hline & Tannic acid & $2.0 \mathrm{~g}$ & \\
\hline & Agar & $20.0 \mathrm{~g}$ & \\
\hline \multirow{7}{*}{ MD4 } & Soil infusion & $400 \mathrm{~mL}$ & \multirow{7}{*}{$\begin{array}{l}\text { R12, R27, L1, L6, } \\
\text { L10, L14, L16 }\end{array}$} \\
\hline & Distilled water & $600 \mathrm{~mL}$ & \\
\hline & $\mathrm{K}_{2} \mathrm{HPO}_{4}$ & $0.5 \mathrm{~g}$ & \\
\hline & $\mathrm{KH}_{2} \mathrm{PO}_{4}$ & $0.5 \mathrm{~g}$ & \\
\hline & $\mathrm{MgSO}_{4}$ & $0.5 \mathrm{~g}$ & \\
\hline & Lignin & $2.0 \mathrm{~g}$ & \\
\hline & Agar & $20.0 \mathrm{~g}$ & \\
\hline
\end{tabular}

TABle 2: Different consortium consisting of different bacterial isolates.

\begin{tabular}{lcc}
\hline S. no. & Bacterial consortium & Bacterial isolates \\
\hline 1 & Consortium C1 & L10, L13, L14, L16 \\
2 & Consortium C2 & R25, R14, L13, L14 \\
3 & Consortium C3 & R27, R12, R1, L1 \\
4 & Consortium C4 & L14, R21, R5, R21 \\
5 & Consortium C5 & R15, R24, L3, L14 \\
6 & Consortium C6 & R10, R12, L6, L14 \\
\hline
\end{tabular}

it is difficult to treat it as such by bacteria. Therefore, it was diluted with effluent generated from paper making process (back water). Back water and black liquor were mixed in different ratios $(60: 40,70: 30$, and $80: 20)$ to dilute the sample.

The pulp and paper effluent is deficient in nitrogen $(\mathrm{N})$ as well as phosphorus (P) constituents, so nitrogen and phosphorus were supplemented during wastewater treatment. Various parameters (temperature, $\mathrm{pH}$, and agitation) were standardized in order to get efficient treatment in less duration.

After the parameters were optimized, the experiments were repeated in order to check the reproducibility among the results with the designed consortium.

2.8. Bacterial Identification. Although $16 \mathrm{~S}$ rRNA gene is found to be conserved on evolutionary scale, it is still diverse enough for identifying and classifying the eubacteria Amann et al. [13]. For $16 \mathrm{~S}$ rRNA sequencing, the bacterial culture was inoculated in Luria Bertani broth (Hi-Media). Overnight grown bacterial culture was used for total DNA isolation using Genomic DNA Extraction kit (Real Biotech Corporation). Universal primers $16 \mathrm{sF}$ (CAGCAGCCGCGGTAATAC) and $16 \mathrm{sR}$ (TACGGCTACCTTGTTACG) were used for amplification of $16 \mathrm{~S}$ rRNA gene. The PCR reaction mixture contained and assay buffer $5 \mu \mathrm{L}$, forward primer 1 microliter, reverse primer 1 microliter, dNTP $1 \mu \mathrm{L}$, template $2 \mu \mathrm{L}$, tag polymerase $1 \mu \mathrm{L}$, and final total volume was made up $50 \mu \mathrm{L}$ with milli Q. Polymerase chain reaction was performed in a thermo cycler (BIORAD) under the following conditions, denaturation at $94^{\circ} \mathrm{C}$ for $1 \mathrm{~min}$, followed by annealing at $55^{\circ} \mathrm{C}$ for $1 \mathrm{~min}$, and extension at $72^{\circ} \mathrm{C}$ for $2 \mathrm{~min}$, for 35 repeated cycles. Approximately, $1500 \mathrm{bp}$ region of the gene was amplified, and the amplification product was gel purified using QIA gel extraction kit and sequenced. The sequence data was analyzed by BLAST and identified based on closest similarity with the reported sequenced data.

\section{Results}

3.1. Characteristics of Wastewater Samples. In the present study, samples were collected from two small paper mills, (mill A) and (mill B) located in Meerut, India. The COD load of wastewater varies from time to time due to use of various raw materials used in pulping and paper making process. COD of effluent of paper making unit (back water) varied from 1200 to $1600 \mathrm{mg} / \mathrm{L}$ in mill A and 1800 to $2000 \mathrm{mg} / \mathrm{L}$ in mill B. Black liquor from two industries showed COD load varied from 13,000 to $15,000 \mathrm{mg} / \mathrm{L}$ in mill $\mathrm{A}$ and 15,000 to $18,000 \mathrm{mg} / \mathrm{L}$ in mill B.

3.2. Isolation of Bacteria. The bacteria were isolated from the soil samples collected from the small-scale pulp and paper mill. It was hypothesized that bacteria isolated from their natural habitat have capability of surviving in harsh conditions by developing some catabolic enzyme systems specific for particular components present in the natural habitat. 45 bacteria were initially isolated from the soil samples. The isolated bacterial colonies were diverse in their morphologies, ranging from small pinpointed to large sized fluorescent to whitish, flat to umbonate, and smooth margined to wrinkled periphery. Total 14 bacteria were selected out of 45 isolates, on the basis of their fast growth on the medium containing carbon source cellulose, xylan, tannic acid, and lignin.

3.3. Screening of the Selected Isolates. Selected 14 bacterial isolates were tested for their COD reduction potential using 
TABle 3: Percentage reduction in COD of sample (back water $100 \%)$ and (back water : black liquor $(60: 40))$ using single isolates after 45 hrs of incubation.

\begin{tabular}{lcccc}
\hline \multirow{4}{*}{ Isolate } & \multicolumn{5}{c}{ Percentage reduction in COD } \\
& Back water $(100 \%)$ & Back water : black water $(60: 40)$ \\
& Mill A & Mill B & Mill A & Mill B \\
\hline R1 & 25 & 19.5 & 15.25 & 10.25 \\
R5 & 30.5 & 25 & 21 & 16 \\
R10 & 31.75 & 25.5 & 22.75 & 22.75 \\
R12 & 37.75 & 36.5 & 15.75 & 11.25 \\
R21 & 34.25 & 27.25 & 25 & 17 \\
R24 & 29.75 & 29.5 & 11.25 & 14.5 \\
R25 & 28.75 & 28.5 & 12.75 & 12 \\
R27 & 31.5 & 21.75 & 13.75 & 11 \\
L1 & 29.5 & 24 & 15 & 15 \\
L6 & 32.25 & 31.5 & 19.75 & 23.5 \\
L10 & 25.25 & 31.75 & 15.75 & 16.75 \\
L13 & 28.5 & 28.5 & 13 & 15.5 \\
L14 & 35.5 & 35.5 & 23.25 & 22.25 \\
L16 & 30 & 30.5 & 15 & 19.25 \\
\hline
\end{tabular}

two types of samples, namely, back water (100\%) and mixture of back water : black liquor in ratio of $60: 40$. The results of these experiments showed that COD reduction in back water was 25-35\% (mill A) and 19.5-36.5\% (mill B). In case of back water and black liquor $(60: 40)$, a reduction of $11.25 \%-23.25 \%$ in mill $\mathrm{A}$ and $10.25 \%-23.5 \%$ in mill $\mathrm{B}$ was observed by using single isolate in $45 \mathrm{~h}$ of incubation (Table 3).

3.4. Screening of Formulated Consortia. Isolates showing maximum COD reduction were used for the formulation of consortia. Total six consortia were formulated, each composed of 4 bacteria. All the six consortia were tested for their COD reduction ability using two types of samples, namely, back water $(100 \%)$ and back water: black liquor $(60: 40)$. The samples were collected from two different mills, Mill A and Mill B. After $45 \mathrm{~h}$ incubation period, COD reduction of back water (100\%) was in the range of 55-60\% (mill A), and for mill $\mathrm{B}$, the reduction was in the range of $49-59 \%$.

Similarly, the results of the experiment performed for back water : black liquor $(60: 40)$ revealed that in case of mill A, the COD reduction ranges from $35 \%$ to $45 \%$ and for mill B, it varies from 49 to $59 \%$ by using consortia C1, C2, C3, C4, C5, and C6 (Figures 1 and 2).

On the basis of results of both types of samples, it can be deduced that the consortium C6 could reduce COD to a greater extent; therefore, this consortium was selected for further experiments.

3.5. Optimization of Parameters. The optimization of different parameters, namely, $\mathrm{pH}$, temperature, agitation, nitrogen, and phosphorus and ratio of back water : black liquor was studied.

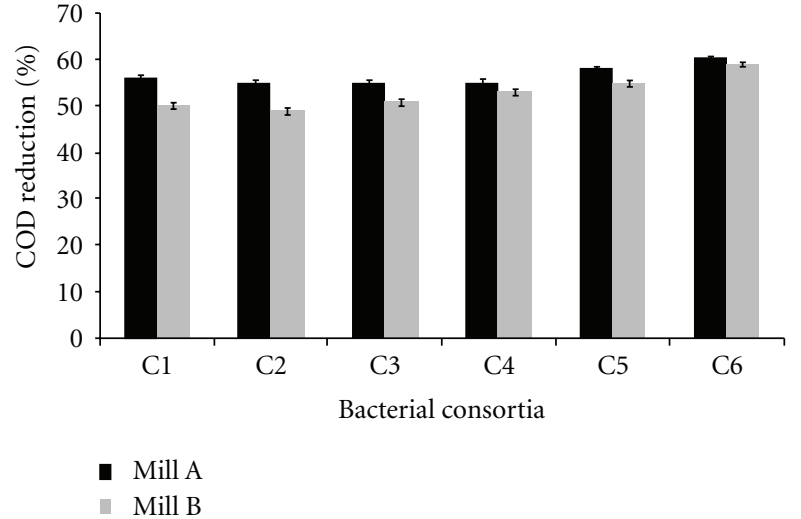

FIGURE 1: COD reduction of sample (back water 100\%) using different consortia after $45 \mathrm{hrs}$ as per control— $1450 \mathrm{mg} / \mathrm{L}$ (mill A) and $1855 \mathrm{mg} / \mathrm{L}$ (mill B).

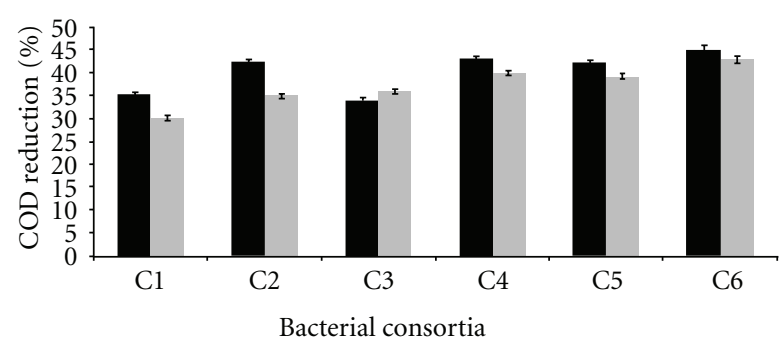

- Mill A

n Mill B

Figure 2: COD reduction of sample back water:black liquor $(60: 40)$ using different consortia after $45 \mathrm{hrs}$ as per control$5800 \mathrm{mg} / \mathrm{L}$ (mill A) and $7850 \mathrm{mg} / \mathrm{L}$ (mill B).

While studying the effect of a range of $\mathrm{pH}$ values ranging from 6.8 to 7.0 to 8.0 , maximum reduction was observed at $\mathrm{pH}$ 6.8. Different temperatures were examined, and maximum reduction was observed at $37^{\circ} \mathrm{C}$. The effect of rate of agitation on the COD reduction was also observed. Agitation at $200 \mathrm{rpm}$ showed the maximum reduction in COD when supplemented with nitrogen and phosphorus. Three different ratios of back water: black liquor $(60: 40,70: 30$, and $80: 20)$ were tested. Maximum reduction was observed when back water : black liquor was used in the ratio of $80: 20$ (Table 4).

3.6. Ratio of Back Water: Black Liquor. In order to see if COD reduction is affected by the dilution ratio of wastewater, the experiment was repeated with varying ratios of back water and black liquor ranging from $60: 40$ to $70: 30$ to $80: 20$. Maximum reduction (Figure 3 ) was observed when back water : black liquor was used in the ratio of $80: 20$.

3.7. Nitrogen and Phosphorus. To check whether COD reduction could be enhanced by addition of nitrogen and phosphorus as nutrients, the experiment was performed with and 
TABLE 4: Percentage reduction in COD values of different optimized parameters for Mill A and Mill B.

\begin{tabular}{|c|c|c|c|c|}
\hline \multirow{3}{*}{ Parameters } & \multicolumn{4}{|c|}{ Percentage reduction in COD after 20 hrs of incubation } \\
\hline & \multicolumn{2}{|c|}{ Back water } & \multicolumn{2}{|c|}{ Back water : black liquor } \\
\hline & Mill A & Mill B & Mill A & Mill B \\
\hline $\mathrm{pH}(6.8)$ & 86.5 & 78.7 & 66 & 61 \\
\hline $\begin{array}{l}\text { Temperature } \\
\left(35^{\circ} \mathrm{C}\right)\end{array}$ & 85 & 78 & 64 & 61.5 \\
\hline $\begin{array}{l}\text { Agitation } \\
(200 \mathrm{rpm})\end{array}$ & 86.25 & 77 & 65 & 60 \\
\hline $\begin{array}{l}\text { Nitrogen }+ \\
\text { Phosphorus }\end{array}$ & 86.5 & 73.75 & 63 & 62 \\
\hline $\begin{array}{l}\text { Ratio }(80: 20) \\
\text { Back water : black } \\
\text { water }\end{array}$ & & & 62.1 & 60.75 \\
\hline
\end{tabular}

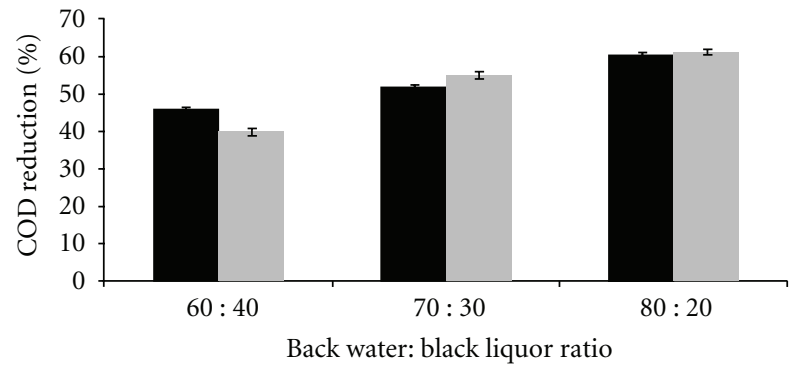

- Mill A

- Mill B

Figure 3: COD reduction of sample back water:black liquor $(60: 40,70: 30$, and $80: 20)$ using C6 consortia after 20 hrs of incubation.

without nitrogen and phosphorus. The experiment was performed by adding nitrogen and phosphorus in back water : black liquor $(80: 20)$, and the results revealed that COD reduction could be achieved in a range of $62-63 \%$ for both mills. However, the COD reduction was reduced to $57-60 \%$ in the absence of nitrogen and phosphorus. Similarly, the experiment was performed using back water (100\%) as a sample where reduction of 73.7-86.5\% was observed in case of both mills. Likewise, the reduction was in the range of $69-75 \%$, in the absence of nitrogen and phosphorus (Supplementary Figures 1(a)-2(a) available online at doi:10.1100/2012/127014). The supplementation of nitrogen and phosphorus enhanced the reduction in COD.

3.8. $p H$. Effect of $\mathrm{pH}$ on $\mathrm{COD}$ reduction was also observed by varying $\mathrm{pH}$ of wastewater from 6.8 to 8.0 , and the results showed that best COD reduction could be achieved in the flask with the $\mathrm{pH}$ 6.8. At this $\mathrm{pH}$, the COD reduction was $66 \%$ for mill $\mathrm{A}$ and $61 \%$ for mill B in back water : black liquor $(60: 40)$. Similarly, in case of back water $(100 \%)$, the reduction in COD was up to $86.5 \%$ for mill A and $78.7 \%$ for mill B (Supplementary Figures 1(b)-2(b)).

3.9. Temperature. The reduction of COD was studied at different temperatures. The results revealed that maximum
COD reduction could be achieved in the flask incubated at $35^{\circ} \mathrm{C}$ as compared to the other flasks incubated at temperatures varying from $25^{\circ} \mathrm{C}$ to $40^{\circ} \mathrm{C}$. The flask containing back water : black liquor incubated at $35^{\circ} \mathrm{C}$ showed $\mathrm{COD}$ reduction up to $64 \%$ for mill $\mathrm{A}$ and $61.5 \%$ for mill $\mathrm{B}$.

After varying the temperature from $35^{\circ} \mathrm{C}$ to $25^{\circ} \mathrm{C}$, it was observed that in case of mill A reduction was up to $60 \%$ and in case of mill B, reduction was 57\%. When temperature was increased to $40^{\circ} \mathrm{C}$, the achieved reduction in case of mill $\mathrm{A}$ was $64 \%$, and for mill B, it was $59 \%$.

Similarly, the experiment was performed by using back water $100 \%$ incubated at different temperatures that is, $25^{\circ} \mathrm{C}$, $35^{\circ} \mathrm{C}$, and $40^{\circ} \mathrm{C}$. At $25^{\circ} \mathrm{C}$, COD reduction was up to $85 \%$ for mill $\mathrm{A}$ and $78 \%$ for mill $\mathrm{B}$. By increasing the temperature to $35^{\circ} \mathrm{C}$, the COD reduction in mill $\mathrm{A}$ was $85 \%$ and in mill $\mathrm{B}$, it was up to $78 \%$. At temperature $40^{\circ} \mathrm{C}$, reduction was upto $80 \%$ for mill A and $75 \%$ for mill B. (Supplementary Figures $1(\mathrm{c})-2(\mathrm{c}))$.

3.10. Agitation. The effect of rate of agitation on the COD reduction was also observed. Studies were conducted at three different rates of agitation-150, 200, and $250 \mathrm{rpm}$. It was observed that in case of back water : black liquor $(80: 20)$ at $200 \mathrm{rpm}$, the COD reduction in case of mill A was $65 \%$ and in case of mill B $60 \%$.

In case of back water (100\%), observed COD reduction was $87 \%$ for mill A and $77 \%$ for mill B. (Supplementary Figures 1(d)-2(d)).

3.11. Repeatability and Reproducibility of Results after Optimization of Parameters. Figure 4 showed maximum COD reduction up to $86.6 \%$ for Mill A and $85 \%$ for of Mill B in case of back water $(100 \%)$, whereas in case of back water : black liquor $(80: 20)$, a reduction of $66.1 \%$ for Mill A and $65 \%$ for Mill B was observed under optimized conditions ( $\mathrm{pH} 6.8$, temperature $35^{\circ} \mathrm{C}$, shaking $200 \mathrm{rpm}$, and supplementation of nitrogen and phosphorus as trace elements).

\section{Discussion}

Agro-based pulp and paper mills are responsible for environmental pollution due to lack of chemical recovery system 


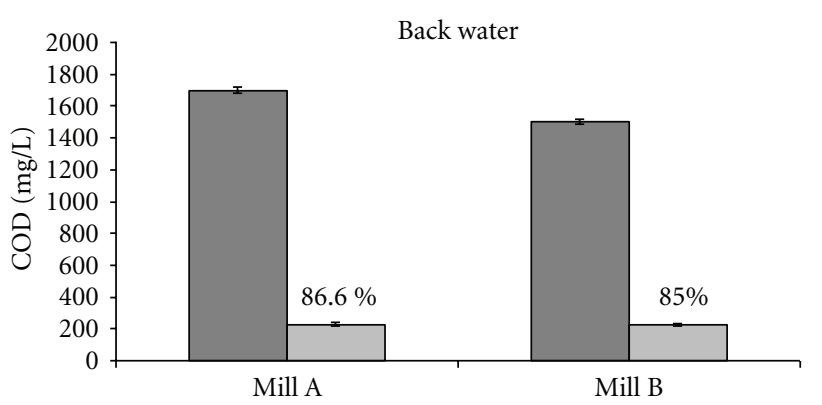

Control COD mg/L

COD mg/L after treatment

(a)

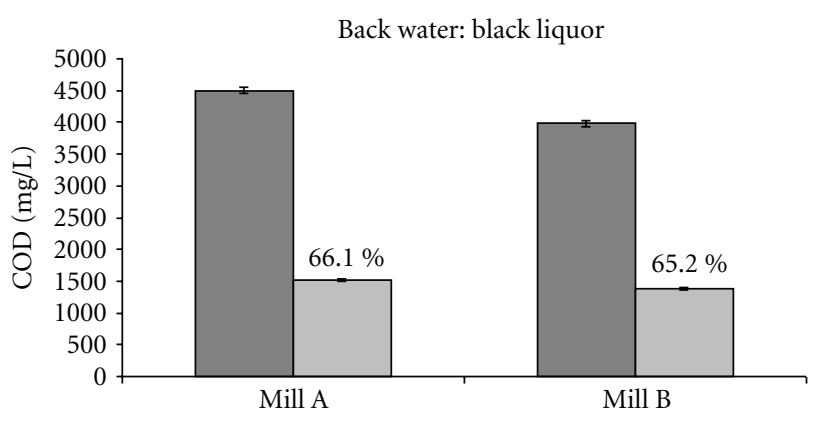

Control COD mg/L

$\square \mathrm{COD} \mathrm{mg} / \mathrm{L}$ after treatment

(b)

Figure 4: COD reduction of sample (back water 100\%) and (back water : black Liquor 80:20) using C6 consortia under optimized conditions ( $\mathrm{pH} 6.8$, temperature $35^{\circ} \mathrm{C}$, and shaking $200 \mathrm{rpm}$ ).

which might be due to insufficient infrastructure and high initial investment.

Black liquor emanating from these industries contains highly polluting constituent like lignin and cooking chemicals, which have deleterious effect on land and natural water bodies. Treatment of such a polluting stream is a big question among the researchers. Some researchers used the physiochemical treatment processes such as electrochemical, ozonation, coagulation adsorption flocculation, Fenton's reagent, and membrane filtration technology to treat the effluent. These technologies are efficient, but all of them are expensive for small-scale agro-based pulp and paper mills to implement for the treatment of effluent [14-16]. Biological treatment of wastewater stream was also explored using various fungi by a number of workers. Freitas et al. [17] used white rot and soft rot fungal species for treatment of the effluent from Kraft pulp mills and showed COD reduction of $74-81 \%$ after 10 days. Wingate et al. [18] explored purified fungal cellobiose dehydrogenate for color remediation of pulp mill effluent and could remove up to 50\% color after 4 days. But, fungal treatment of agro-based pulp and paper mills effluent was not feasible because fungi are unable to proliferate under extreme environmental conditions (high $\mathrm{pH}$, temperature, and oxygen limitation) that are present in effluent treatment plant of agro-based pulp and paper mills. In addition, fungal filaments cause structural hindrance in effluent treatment plants.

In order to have efficient treatment system, it is imperative to reduce COD, BOD, color, and so forth in minimum retention time. Therefore, specific bacteria were isolated which could degrade organic substances present in the effluent generated from pulp and paper mills. Bacterial treatment of pulp and paper wastewater has been studied by various research groups. Singh et al. [19] used mixed culture of two bacterial strains, Bacillus sp. and Serrantia marcescens to reduce COD, BOD, TS, TDS, TSS and showed degradation of pentachlorophenol up to $94 \%$ after $168 \mathrm{~h}$ by addition of glucose and peptone as additional nutrient source. Chandra et al. [20] showed COD reduction up to $90 \%$ after 7 days by using a mixed culture of two bacteria and supplementing the sample with glucose and peptone. It has been reported earlier that the reduction in COD/BOD is concurrent to the decrease in chlorolignins \& chlorophenols. Raj et al. [7] explored bacterial strains for Kraft lignin degradation and reported reduction of color and Kraft lignin by $65 \%$ and $37 \%$, respectively, after 6-day incubation period by adding cosubstrate glucose and peptone.

In the present study, different bacterial isolates were isolated from soil collected from industrial premises. Bacteria isolated directly from soil are expected to be able to adapt to the extreme environment easily and more efficiently biodegrade the pollutant. This is of particular advantage over the fungal treatment of pulp and paper mill effluent. Besides, the bacterial treatments discussed above treat the wastewater in a range of 6-7 days. Agro-based pulp mill effluent contains polysaccharides, lignin, tannic acid, cellulose, hemicelluloses, and many other natural compounds. Black liquor is highly concentrated, and COD load is $15000-18000 \mathrm{mg} / \mathrm{L}$. Its biodegradation is difficult as such, so black liquor was diluted by adding wastewater generated from other paper manufacturing process, that is, paper making unit (back water). The selected bacteria were used in different combinations to check whether their synergism might aid better COD reduction. Based on the results, consortium C6 was selected for further optimization. The selected consortium was found to have good potential to biodegrade the effluent generated from agro-based pulp and paper mills without any additional carbon source. It was able to reduce COD load up to $65-85 \%$ within 20 hours under optimized conditions of $\mathrm{pH}$, temperature, and agitation.

4.1. Identification of Bacterial Isolates. Identification of bacterial isolates of consortium was carried out by $16 \mathrm{~S} \mathrm{rDNA}$ studies. The amplified $16 \mathrm{~S}$ rRNA gene sequence of L14, R12, R10, and L6 has been submitted to GenBank under accession numbers GU433442, GU433443, GU433444, and GU433445, respectively. These sequences were queried against the available DNA sequence at NCBI using BLAST tool and were found to be most similar to sequences from 
Pseudomonas sp. (GI-218685709, 99\%), Bacillus sp. (GI113196068, 99\%), Pannonibacter sp. (GI-14272366, 99\%), and Ochrobacterum sp. (GI- 223470224, 100\%), respectively.

\section{Conclusion}

The results showed that autochthonous bacteria isolated from the site of pulp and paper mill have the ability to use lignin, tannic acid, xylan, and cellulose as carbon source and reduce the COD value up to $86.5 \%$ (back water) and $65 \%$ $(80: 20$, back water and black liquor mixture) of effluent generated from small (agro-based) pulp and paper mills within 20 hours of incubation under optimized conditions. After comparing the results with previous studies, the time taken to COD reduction process was very less in our case.

\section{Acknowledgments}

The authors acknowledge the financial help provided by the Department of Biotechnology, Government of India. The authors also acknowledge the small-scale paper mill authorities for extending their cooperation for providing wastewater samples, whenever required, and the generous hospitality offered to us upon each visit. They are also thankful to CSIR for providing the necessary infrastructure.

\section{References}

[1] S. Singh, "An overview of Indian agro-based paper mills," in Liquid Asset, Proceedings of the Indo-EU Workshop on Promoting Efficient Water Use in Agro Based Industries, P. K. Tewari, Ed., pp. 31-33, TERI Press, New Delhi, India, 2004.

[2] R. M. Mathur, S. Panwar, M. K. Gupta, N. Endlay, and A. G. Kulkarni, "Agro-based pulp and paper mills: environmental status, issues and challenges and the role of Central Pulp and Paper Research Institute," in Liquid Asset, Proceedings of the Indo-EU Workshop on Promoting Efficient Water Use in Agro Based Industries, P. K. Tewari, Ed., pp. 99-114, TERI Press, New Delhi, India, 2004.

[3] K. Schumacher and J. Sathaye, India's Pulp and Paper Industry: Productivity and Energy Efficiency, Energy Analysis Program Environmental Energy Technologies, Division Lawrence Berkeley National Laboratory, Berkeley, Calif, USA, 1999.

[4] M. Ali and T. R. Sreekrishnan, "Aquatic toxicity from pulp and paper mill effluents: a review," Advances in Environmental Research, vol. 5, no. 2, pp. 175-196, 2001.

[5] P. K. Srivastava, J. Sathaye, A. Gadgil, and M. Mukhopadhyay, "Energy efficiency and environmental management options in the indian pulp and paper industry," ADB Technical Assistance Project (TA: 2403-IND), ERI, Forest Knolls, Calif, USA, 1998.

[6] D. S. Argyropoulos and S. B. Menachem, "Lignin," in Advances in Biochemical Engineering/Biotechnology, K.-E. Eriksson, Ed., vol. 57, chapter 12, pp. 292-322, Springer, New York, NY, USA, 1997.

[7] A. Raj, M. M. K. Reddy, R. Chandra, H. J. Purohit, and A. Kapley, "Biodegradation of kraft-lignin by Bacillus sp. isolated from sludge of pulp and paper mill," Biodegradation, vol. 18, no. 6, pp. 783-792, 2007.

[8] D. Pokhrel and T. Viraraghavan, "Treatment of pulp and paper mill wastewater-a review," Science of the Total Environment, vol. 333, no. 1-3, pp. 37-58, 2004.
[9] R. Kirby, "Actinomycetes and lignin degradation," Advances in Applied Microbiology, vol. 58, pp. 125-168, 2005.

[10] H. Gao, Y. Wang, W. Zhang, W. Wang, and Z. Mu, "Isolation, identification and application in lignin degradation of an ascomycete GHJ-4," African Journal of Biotechnology, vol. 10, no. 20, pp. 4166-4174, 2011.

[11] A. Amr, E. l. Hanafy, E. Hassan, H. E. Abd-Elsalam, and E. Elsayed, "Molecular characterization of two native egyptian ligninolytic bacterial strains," Journal of Applied Sciences Research, vol. 4, pp. 1291-1296, 2009.

[12] Standard Methods for the Examination of Water and Wastewater, American Public Health Association/American Water Works Association/Water Environment Federation, Washington, DC, USA, 1998.

[13] R. I. Amann, W. Ludwig, and K. H. Schleifer, "Phylogenetic identification and in situ detection of individual microbial cells without cultivation," Microbiological Reviews, vol. 59, no. 1, pp. 143-169, 1995.

[14] E. C. Catalkaya and F. Kargi, "Advanced oxidation treatment of pulp mill effluent for TOC and toxicity removals," Journal of Environmental Management, vol. 87, no. 3, pp. 396-404, 2008.

[15] Y. S. Hong, H. Zhou, and R. G. Zytner, "Combining ultrafiltration process with coagulation pretreatment for pulp mill wastewater treatment," Environmental Technology, vol. 28, no. 9, pp. 995-1006, 2007.

[16] S. Mahesh, B. Prasad, I. D. Mall, and I. M. Mishra, "Electrochemical degradation of pulp and paper mill wastewater. Part 1. COD and color removal," Industrial and Engineering Chemistry Research, vol. 45, no. 8, pp. 2830-2839, 2006.

[17] A. C. Freitas, F. Ferreira, A. M. Costa et al., "Biological treatment of the effluent from a bleached kraft pulp mill using basidiomycete and zygomycete fungi," Science of the Total Environment, vol. 407, no. 10, pp. 3282-3289, 2009.

[18] K. G. Wingate, T. Stuthridge, and S. D. Mansfield, "Colour remediation of pulp mill effluent using purified fungal cellobiose dehydrogenase: reaction optimisation and mechanism of degradation," Biotechnology and Bioengineering, vol. 90, no. 1, pp. 95-106, 2005.

[19] S. Singh, R. Chandra, D. K. Patel, M. M. K. Reddy, and V. Rai, "Investigation of the biotransformation of pentachlorophenol and pulp paper mill effluent decolorisation by the bacterial strains in a mixed culture," Bioresource Technology, vol. 99, no. 13, pp. 5703-5709, 2008.

[20] R. Chandra, A. Raj, S. Yadav, and D. K. Patel, "Reduction of pollutants in pulp paper mill effluent treated by PCP-degrading bacterial strains," Environmental Monitoring and Assessment, vol. 155, no. 1-4, pp. 1-11, 2009. 

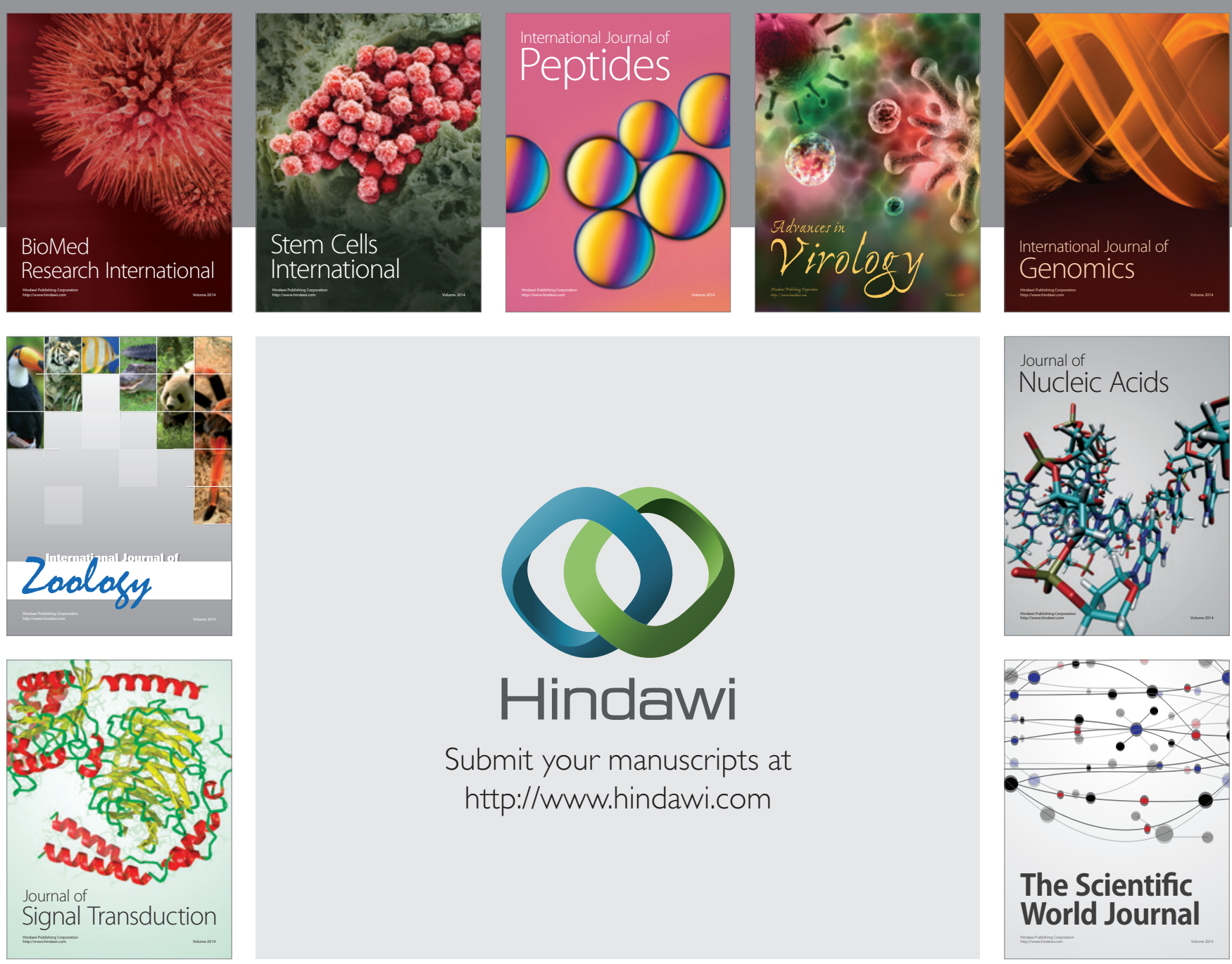

Submit your manuscripts at

http://www.hindawi.com
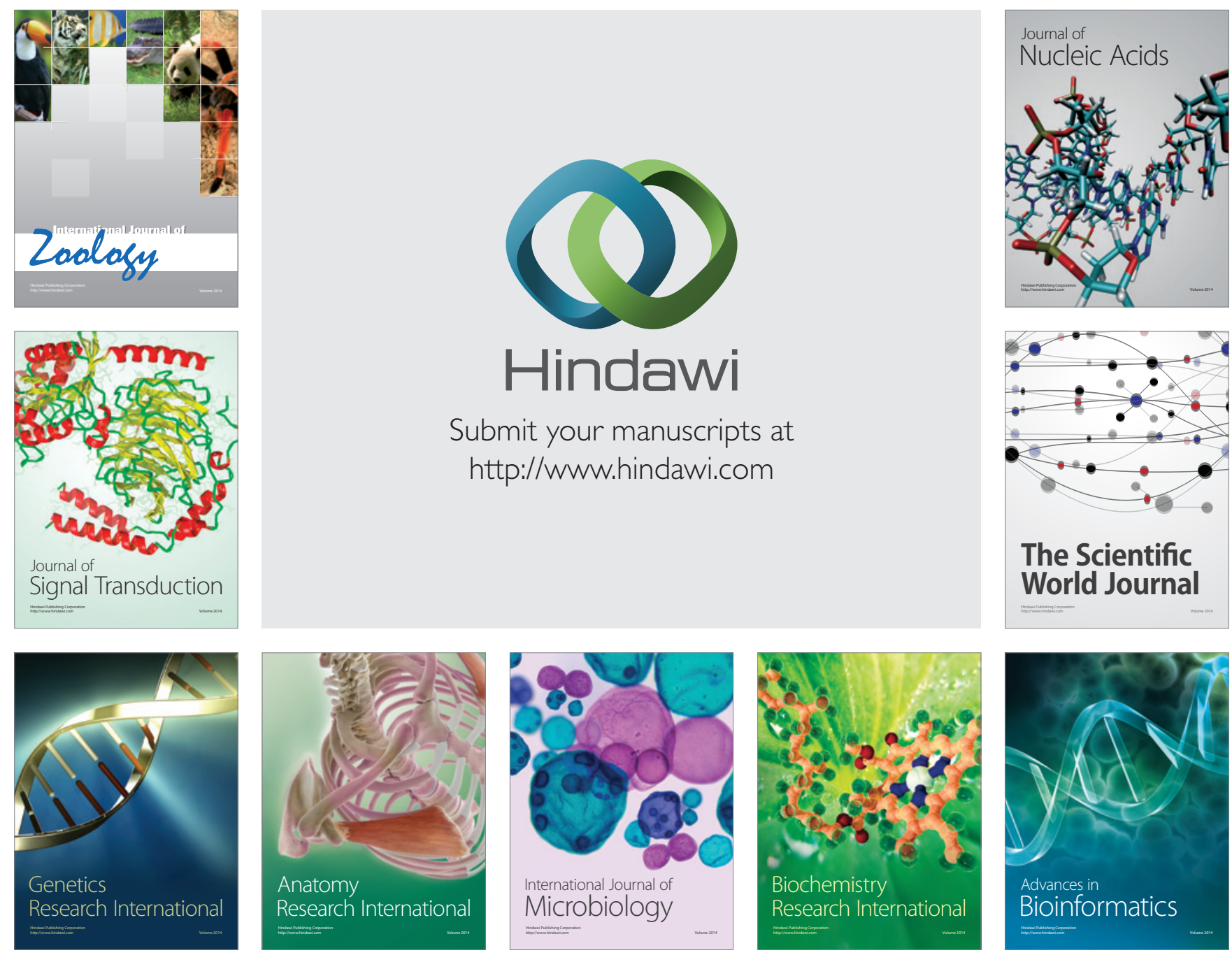

The Scientific World Journal
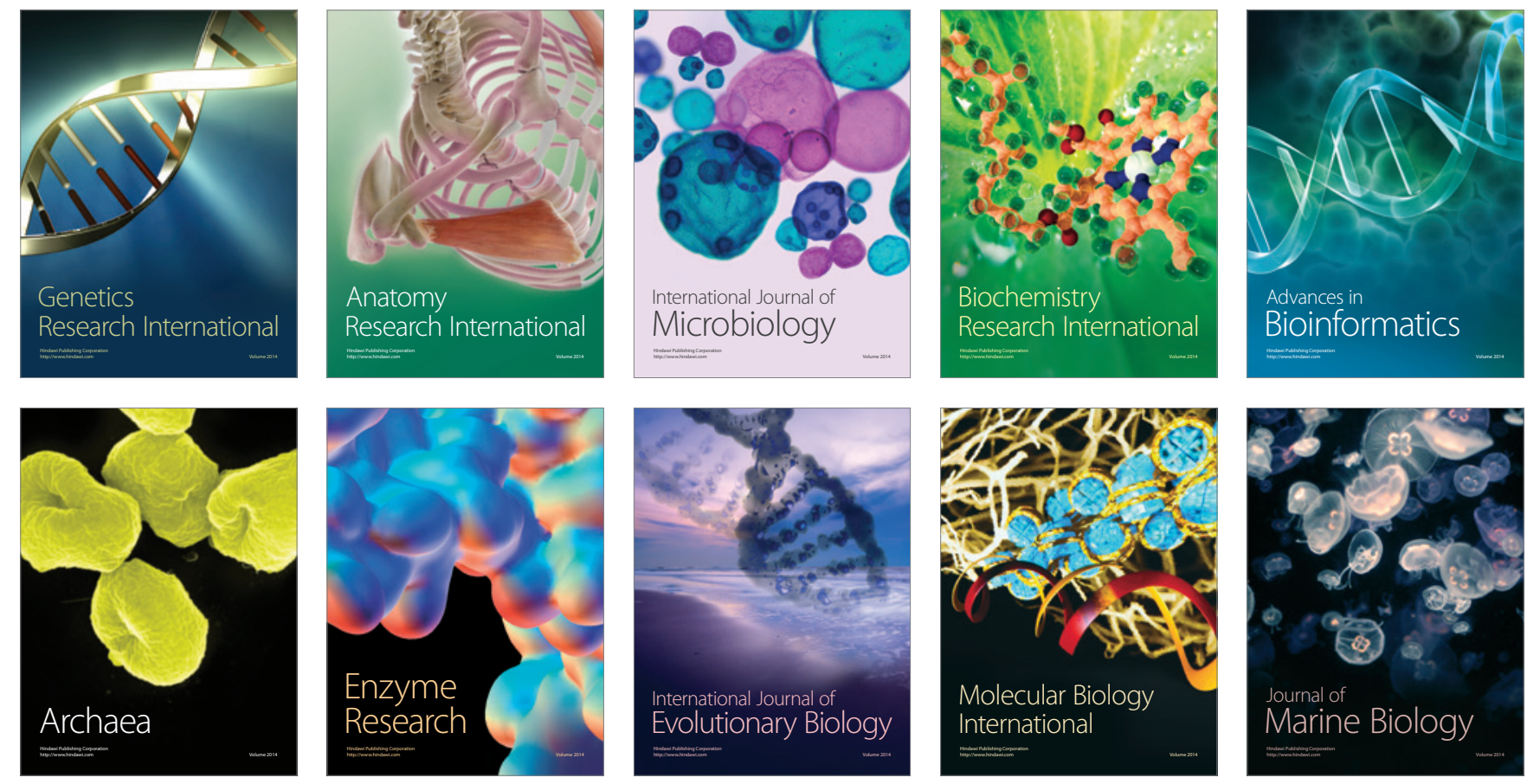